\title{
PENGARUH PYRAMID OF STRUCTURE DAN PENGUNGKAPAN TRANSAKSI PIHAK BERELASI TERHADAP TINDAKAN EKSPROPRIASI, DIMODERASI OLEHTATA KELOLA PERUSAHAAN
}

\author{
Fadli Fendi Malawat \\ Sutrisno \\ Imam Subekti \\ Universitas Brawijaya
}

\begin{abstract}
The objective of this study is to analyze the effect of company's ownership through pyramid structure, and related party transaction disclousure, on expropriation practices, with corporate governance as moderating variable. The concept of expropriation practices in this study is measured by related party transaction assets, liabilities (RPT AL) and related party transaction sales, expenses (RPT SE). Analytical technique used is hierarchical regression analysis for testing hypotheses developed in this study. Research population is a manufacturing company listed in Indonesia Stock Exchange (IDX) during years 2014-2016, and the sample is selected using purposive sampling method. The results of this study fails to prove effect of company's ownership through pyramid structure, and related party transaction disclousure on expropriation practices. Furthermore, this study indicates the corporate governance can to increase the level of related party transactions disclosure, but has not been to reduce the expropriation practices caused by company's ownership through pyramid structure. This study contributes to the theory of agency type II which discusses conflict of interest between controlling and non-controlling shareholders, especially the problem of information asymmetry, which can be minimized by the role of corporate governance.
\end{abstract}

Keywords: pyramid of structure, related party transactions disclosure, corporate governance, expropriation, and related party transactions (RPT).

\section{PENDAHULUAN}

Kajian empiris penelitian

sebelumnya, menemukan bahwa pemegang saham pengendali melakukan ekspropriasi dengan tunneling activities, (La Porta et al.,1999a; Johnson et al., 2000; Glaeser et al., 2001; Chang, 2003; Cheung et al, 2006). Tunneling merupakan transfer sumber daya dari perusahaan untuk kepentingan pihak tertentu melalui self-dealing transactions. Transaksi tersebut termasuk tindakan pencurian atau penipuan, yang ilegal, seperti transaksi pembelian dan penjualan aset dibawah harga pasar, penyewaaan aset, kompensasi eksekutif yang berlebihan, dan pemberian jaminan atas pinjaman dari perusahaan. Tunneling merupakan salah satu bentuk ekspropriasi, yang biasanya di jembatani oleh transaksi antar perusahaan berafiliasi yang memiliki hubungan istimewa, dan umumnya transaksi ini disebut dengan transaksi pihak berelasi atau related party transactions (RPT). 
Penelitian sebelumnya yang mendeteksi tunneling sebagai akibat dari tindakan ekspropriasi melalui RPT, antara lain; Ying \& Wang (2013), Kang et al. (2014), Dewi, (2014), Pozzoli \& Venuti, (2014), dan Utama \& Utama (2014). Transaksi pihak berelasi dilakukan oleh direksi perusahaan sebagai pemegang saham pengendali dengan pihak-pihak yang masih memiliki hubungan keluarga diantara mereka sendiri. Fenomena kasus di Indonesia yang telah terindikasi maupun terbukti melakukan tindakan ekspropriasi yang merugikan pemegang saham nonpengendali yaitu, terjadi pada PT Sumalindo Lestari Jaya Tbk (SULI). Ditemukan adanya transaksi yang mengandung benturan kepentingan serta rendahnya asas transparansi dalam berbagai kegiatan perusahaan. Dewan direksi dan pemegang saham mayoritas diduga turut andil dalam transaksi afiliasi yang menimbulkan kerugian pemegang saham minoritas.

Beberapa transaksi yang dianggap merugikan PT. SULI yaitu; pertama, Transaksi inbreng aset Hutan Tanaman Industri, atau pelepasan aset oleh SULI kepada anak perusahaannya yaitu, PT. Sumalindo Alam Lestari, dengan nilai transaksi yang tidak wajar. Bahkan informasi transaksi tersebut tidak pernah diungkapkan pada RUPS dan RUPS-LB kepada pemegang saham minoritas. Kedua, Pembelian Zero Coupond Bond yang diterbitkan oleh PT. Sumalindo Hutani Jaya (anak), tanpa ada jaminan hutang. Selain itu ditemukan pemegang saham pengendali yang menjabat sebagai dewan komisaris atau direksi pada perusahaan induk dan anak, atas nama David. Panggabean (2013), dalam liputan6.com mengungkapkan bahwa, seluruh pemegang saham PT. SULI semuanya memiliki hubungan kekeluargaan yang berpotensi terjadinya conflict of interest. pemegang saham mayoritas PT. SULI adalah keluarga Sunarko. Fakta hubungan kekerabatan di antara direksi dan pengendali saham mayoritas PT. SULI ini sangat mempengaruhi semua kebijakan yang terjadi yang berorientasi kepada keuntungan sepihak dan sesaat juga telah merugikan kepentingan pemegang saham minoritas atau publik

Peneliti-peneliti sebelumnya berpendapat bahwa, RPT dapat dianggap sebagai bisnis yang sehat, dalam memenuhi kebutuhan perusahaan, meningkatkan efisiensi melalui penciptaan pasar internal dalam kelompok perusahaan. RPT ini disebut sebagai propping, atau efficient transaction hypothesis (Friedman et al. 2003; Pozzoli \& venuti 2014). Ketika 
perusahaan berada pada risiko tingkat menengah, pemegang saham pengendali mempunyai insentif yang kuat untuk melakukan "propped up". Begitu mereka telah berhasil dalam melakukannya, pemegang saham ini kemudian terlibat dalam tunneling melalui transaksi pihak berelasi (Ying \& Wang, 2013). Oleh karena itu, pemangku kepentingan harus memperhatikan relation party transaction (RPT) sebagai peluang adanya tindakan ekspropriasi. Berbeda dari penelitian sebelumnya yang melihat adanya ekspropriasi dari besaran RPT berdasarkan sales dan purchases (Cheung et al., 2006; Ying \& Wang, 2013; Kang et al., 2014; Dewi, 2014; Pozzoli \& Venuti, 2014;), dan kemudian penelitian yang dilakukan oleh Utama \& Utama (2014), yang hanya mengukur besaran RPT dari proksi aset dan liabilitas. Penelitian ini mencoba dikembangkan dengan melihat besara RPT pada pos keuangan seperti, laporan labarugi (sales dan expenses) dan neraca (asset dan liabilities) yang di anggap relevan dalam laporan keuangan memiliki proposisi hubungan istimewa dengan pihak berelasi yang akan di bandingkan dengan total ekuitas perusahaan.

Penelitian ini dibangun berdasarkan literatur sebelumnya, dan menggunakan kerangka teori agensi tipe ke II untuk menyikapi permasalahan yang telah diuraikan. Berdirinya suatu perusahaan dengan struktur kepemilikan terkonsentrasi, melalui model struktur kepemilikan piramida atau pyramid of structure akan memunculkan pemegang saham pengendali atau keluarga yang cenderung akan terlibat sebagai insider. Sebagai insider, pemegang saham pengendali akan memiliki banyak informasi dan memiliki kendali penuh atas perusahaan. Timbulnya masalah agensi pada perusahaan yang dikendalikan oleh pihak keluarga disebabkan oleh konflik antara pemegang saham pengendali dan nonpengendali, bukan konflik tradisional antara pemilik dan manajer. (Fama \& Jensen, 1983; Jensen \& Meckling, 1976; Nekhili \& Cherif, 2011; Du et al., 2013; Fernando et al., 2013).

Kendali atas perusahaan akan didasarkan pada fenomena pemisahan antara hak kontrol (Control Right atau CR) dan hak arus kas (Cash Flow Right atau CFR). Selain itu, masalah asimetri informasi dapat mempengaruhi pengungkapan laporan keuangan sebagai informasi perusahaan kepada publik. Bahkan, Henry et al. (2012) menunjukkan keprihatinan kritis mengenai pengungkapan RPT : "Masalahnya adalah transaksi yang dilaporkan, jika tidak 
diidentifikasi sebagai adanya transaksi hubungan pihak berelasi, maka akan mendistorsi realitas ekonomi melalui posisi keuangan perusahaan. Lebih lanjut, penelitian ini akan mengkaji mekanisme pengawasan yang dapat menjamin hak-hak minoritas, yaitu dengan menerapkan sistem tata kelola perusahaan yang baik (Good Corporate Governance atau GCG) pada perusahaan tersebut (Lin et al. 2014). Tujuan dari penelitian ini adalah, Untuk menguji dan memberikan bukti empiris pengaruh kosentrasi kepemilikan melalui pyramid of structure, dan menilai pengungkapan transaksi pihak berelasi yang diwajibkan oleh regulasi di Indoneisa, terhadap tindakan ekspropriasi. Selain itu, dalam penelitian ini akan diuji efektifitas peran mekanisme tata kelola perusahaan sebagai upaya mereduksi kosentrasi kepemilikan melalui pyramid of structure dan meningkatkan transparansi laporan keuangan, khususnya pengungkapan transaksi pihak berelasi.

\section{TINJAUAN PUSTAKA DAN PENGEMBANGAN HIPOTESIS}

\section{Teori Agensi}

Teori agensi telah dikenal pada kalangan akademis khususnya di bidang akuntansi, yang mulanya diprakarsai oleh Jensen \& Meckling (1967). Prinsip utama teori ini menjelaskan hubungan agensi ada ketika, pendelegasian wewenang yang diberikan oleh pemilik (principal) kepada manajer (agent) sebagai pihak penerima wewenang. Ketika agent tidak melaksanakan tugasnya sesuai kepentingan principal, maka akan timbul masalah agensi (agency problem). Agent atau manajer dengan banyak informasi yang dimiliki akan mampu mengusai perusahaan, dan cenderung tidak membagiakan informasi tersebut kepada pihak principal. Asimetri informasi dapat memberikan celah kepada manajer untuk dapat mempengaruhi angkaangka akuntansi yang disajikan dalam laporan keuangan (Dewi, 2014).

Perkembangan perekonomian saat ini, khususnya dalam bidang akuntansi, menjadikan teori agensi kini semakin banyak digunakan untuk menjelaskan permasalahan pada perusahaan. Beberapa peneliti telah mengembangkan permasalahan yang terjadi pada perusahaan yang disebabkan karena benturan kepentingan atau conflict of interest yang disebut sebagai masalah agensi tipe II. Dalam artikel, Pagano \& Röell (1998), menganalisis secara optimal dispersi pemegang saham, dari perspektif pemegang saham pengendali perusahaan. Mereka menyatakan bahwa : 
"The main conflict of interest is that between the controlling shareholder and the minority shareholders, rather than between hired managers and the generality of shareholders".

Pada negara-negara dengan kepemilikan saham perusahaan terkonsolidasi atau terkonsentrasi sering terjadi benturan kepentingan antara pemegang saham pengendali dan pemegang saham nonpengendali, namun bukan lagi sebaliknya antara manajer dan generalitas pemegang saham. Ketika pemegang saham pengendali berinisiatif untuk mengendalikan perusahaan, maka sebagian besar dari mereka akan terlibat sebagai pihak insider atau manajer perusahaan. Dengan demikian, mereka akan memanfaatkan hal tersebut untuk mendapatkan keuntungan pribadi dengan pembebanan diberikan kepada pemegang saham non-pengendali. Secara probabilitas tindakan ekspropriasi didalam perusahaan akan dilakukan karena kecenderungan pemegang saham pengendali memiliki hak kontrol yang lebih besar dari pada hak arus kasnya melalui mekanisme kepemilikan terkonsentrasi. Hal ini akan berdampak pada timbulnya masalah ketidak asimetrian informasi.

\section{Struktur Piramida (Pyramid of Structure)}

Pyramid of Structure merupakan bentuk dari struktur kepemilikan, yang sering digunakan oleh perusahaanperusahaan di Indonesia. Penelitian ini akan menganalisa kepemilkan terkonsentrasi sampai pengendali akhir dengan menggunakan konsep struktur piramida. Kepemilikan atas perusahaan dapat tercermin pada lembar saham, yaitu hak arus kas masing-masing pemegang saham melalui laba. Hal ini berdasarkan aturan pada umumnya one share one vote (Grossman \& Hart, 1987). Akan tetapi dengan struktur kepemilikan piramida, aturan tersebut dapat berubah melalui ketidakseimbangan antara hak kontrol dan hak arus kas.

Dalam penelitian yang dilakukan oleh Cheung et al. (2006), Siregar (2007; 2008), Kang et al. (2014) Lin et al. (2014), dan Yodhianto \& Diyanty (2016), menyatakan bahwa kepemilikan terkonsentrasi dapat diproksikan dengan deviasi antara hak kontrol dan hak arus kas pengendali akhir dalam rantai kepemilikan, sehingga dapat diketahui adanya upaya peningkatan kontrol melalui mekanisme pyramid of structure. Kang et al. (2014), Lin et al. (2014), dan Siregar (2007), menemukan adanya pengaruh negatif antara cash flow right leverage atau peningkatan 
kontrol terhadap nilai perusahan, melalui kebijakan deviden ketika pemegang saham pengendali terlibat dalam manajemen perusahaan. Hal sebaliknya ditemukan oleh penelitian Cheung et al. (2006), dan Siregar (2008), yang menunjukan bahwa tidak ada pengaruh antara cash flow right leverage dengan ekspropriasi yang dapat menyebabkan penilaian perusahaan semakin rendah.

Hasil penelitian yang berbeda oleh Dyanty et al. (2012) dan Fitri (2015), menunjukan bahwa struktur kepemilikan berpengaruh positif terhadap risiko ekspropriasi. Hal ini dipengaruhi oleh adanya kepemilikan terkonsentrasi sehingga muncul hak kontrol yang terpusat oleh pengendali/pihak keluarga. Kondisi seperti ini, memiliki peluang besar terjadinya ekspropriasi terhadap pemegang saham non pengendali. Kemudian hasil yang sama juga ditemukan Yodhianto \& Diyanty (2016), terdapat pengaruh positif antara efek entrenchment dengan ekspropriasi yang berdampak pada biaya hutang. Oleh karena itu, mengingat ekspropriasi dapat dilakukan dengan memanfaatkan hubungan pihak berelasi atau RPT. Maka dapat dirumuskan hipotesis penelitian sebagai berikut :
H1: Pyramid of structure berpengaruh positif terhadap tindakan ekspropriasi

\section{H1a: Pyramid of structure berpengaruh positif terhadap RPT $A L$}

\section{H1b: Pyramid of structure berpengaruh positif terhadap RPT SE}

\section{Pengungkapan Transaksi Pihak Berelasi}

Penelitian oleh, Apriani (2015), mengungkapkan bahwa, struktur kepemilikan dalam perusahaan dapat mempengaruhi pengungkapan oleh perusahaan, khususnya terjadi pada perusahaan go public di Asia Timur yang menganut sistem civil law dengan perlindungan hukum yang lemah. Bahkan, Henry et al. (2012), menunjukkan keprihatinan kritis mengenai pengungkapan RPT: "Masalahnya adalah, transaksi yang dilaporkan atau diungkapkan, jika tidak diidentifikasi sebagai adanya hubungan pihak berelasi, maka akan mendistorsi realitas ekonomi melalui posisi keuangan perusahaan". Oleh karenanya, pengungkapan RPT dibenarkan untuk pemantauan yang efektif dari transaksi tersebut berdasarkan Standar Akuntansi Internasional (IAS) 24 yang diadopsi PSAK no. 7 (Penyesuaian 2015) dan Bapepam-LK no VIII.G.7 tentang hubungan pihak berelasi: mengharuskan perusahaan untuk 
mengungkapkan hubungan pihak berelasi, kompensasi personil manajemen kunci dan sifat transaksi.

\section{Penelitian Otaviana (2016),} menemukan bukti bahwa dominasi kepemilikaan perusahaan oleh keluarga, menyebabkan semakin rendah tingkat pengungkapan laporan keuangan. Lebih lanjut, Peng et al. (2011), dan Cheung et al. (2006), menemukan bukti bahwa mengungkapkan transaksi pihak berelasi dapat menyebabkan reaksi pasar yang negatif, dan secara tidak langsung diangggap sebagai tindakan ekspropriasi terhadap pemegang saham minoritas. Hwang et al. (2013), mengemukakan bahwa rendahnya transparansi dapat menyebabkan manajeman melakukan tindakan ekspropriasi melalui transaksi pihak terkait (RPT), seperti kesempatan untuk memanipulasi laba yang dilaporkan. Utama (2015), menemukan bukti bahwa, terdapat pengaruh positif antara tingkat pengungkapan RPT terhadap besaran RPT. Hal ini didukung oleh penelitian yang dilakukan oleh Utama \& Utama (2014), menemukan hasil yang sama.

Namun pada penelitian yang dilakukan oleh Juvita \& siregar (2013), menemukan bukti yang berbeda, bahwa pengungkapan RPT memiliki pengaruh signifikan negatif antara besaran RPT dengan ekspropriasi melalui manajemen laba. Artinya, tingkat pengungkapan RPT dapat memperkecil tindakan ekspropriasi yang dilakukan perusahaan. Oleh karena itu dapat dirumuskan hipotesis penelitian sebagai berikut :

\section{H2 : Pengungkapan RPT berpengaruh negatif terhadap tindakan ekspropriasi}

\section{H2a: Pengungkapan RPT berpengaruh negatif terhadap RPT AL}

\section{H2b: Pengungkapan RPT berpengaruh negatif terhadap RPT SE}

\section{Tata Kelola Perusahaan (Corporate Governance)}

Tata kelola perusahaan dapat menjadi insentif melalui ukuran kinerja, guna meningkatkan kesuksesan sebuah perusahaan. Terlebihnya lagi, dapat meningkatkan kesejahteraan melalui penilaian akuntabilitas dan transparansi, sehingga mampu meningkatkan nilai perusahaan, yang didistribusikan secara merata dan dapat dipertanggungjawabkan. Menurut, Lukviarman (2016), menegaskan bahwa konsepsi dari corporate governance (CG) akan selalu muncul ketika peran dari institional investors sebagai pemegang saham pengendali memiliki dorongan untuk melakukan perubahan pada perusahaan. 
Dalam kasus yang sebelumnya ditemukan adanya dorongan pemegang saham pengendali untuk menentukan kebijakan perusahaan secara sepihak, tanpa mempertimbangkan keputusan dari pemegang non pengendali. Oleh karena itu, perlu dilakukan kajian dan analisis tentang penilaian praktik corporate governance yang diharapkan dapat meminimalisasi tindakan ekspropriasi.

Bukti empiris dari penelitian sebelumnya mengungkapkan bahwa tindakan ekspropriasi akibat dari kontrol yang berlebihan oleh pemegang saham pengendali dapat di minimalisasi dengan penerapan tata kelola perusahaan (Liu et al., 2007; Dyanty et al., 2012; Utama, 2015). Hasil penelitian yang dilakukan oleh Dyanty et al. (2012), menunjukan bahwa tingkat efektifitas penerapan mekanisme CG dapat mengurangi pengaruh cash flow leverage pemegang saham pengendali terhadap besaran transaksi pihak berelasi. Oleh karenanya, dapat dirumuskan hipotesis penelitian sebagai berikut :

\section{H3: Tata Kelola Perusahaan memperlemah pengaruh positif antara Pyramid of structure terhadap tindakan ekspropriasi}

\section{H3a: Tata Kelola Perusahaan memperlemah pengaruh positif}

\section{antara Pyramid of structure terhadap RPT AL}

\section{H3b: Tata Kelola Perusahaan memperlemah pengaruh positif antara Pyramid of structure terhadap RPT SE}

Ketidakasimetrian informasi yang terjadi dalam perusahaan menyebabkan kecilnya kualitas informasi yang akan di ungkapkan. Oleh sebab itu, pungungkapan laporan keuangan yang bersifat transparan juga akan menjadi masalah. Seperti pembahasan pada bab sebelumnya bahwa, pihak pemegang saham pengendali yang terlibat sebagai insider, dikhawatirkan akan memberikan sedikit informasi perusahaan sehingga akan merugikan pihak non pengendali. Oleh karena itu, diperlukan peran dari atribut internal tata kelola perusahaan guna menyelesaikan masalah tersebut berdasarkan prinsip good corporate governance.

Beberapa bukti empiris oleh, Utama (2015); Juvita \& Siregar (2013); Akmyga \& Mita (2015), dan Yodhianto \& Diyanty (2016), menemukan pengaruh positif yang signifikan dari corporate governance dalam upaya meningkatkan kualitas informasi perusahaan sehingga dapat mengurangi tindakan ekspropriasi. Mereka memproksikan konsep dari variable tata 
kelola perusahaan berbeda-beda, seperti halnya Utama (2015), berdasarkan prinsip GCG (good corporate governance). Kemudian, Juvita \& Siregar (2013), berdasarkan Komite Audit dan Dewan Komisaris Independen, sedangkan Yodhianto \& Diyanty (2016), hanya berdasarkan komposisi dewan komisaris Independen karena dianggap memiliki pengaruh yang signifikan. Maka berdasarkan hasil penelitian ini dapat dirumuskan hipotesis penelitian sebagai berikut :

\section{H4: Tata Kelola Perusahaan memperkuat pengaruh negatif antara Pengungkapan RPT terhadap tindakan Ekspropriasi}

H4a: Tata Kelola Perusahaan memperkuat pengaruh negatif antara Pengungkapan RPT terhadap RPT AL

\section{H4b: Tata Kelola Perusahaan memperkuat pengaruh negatif antara Pengungkapan RPT terhadap RPT SE}

\section{METODE PENELITIAN}

\section{Populasi dan Sampel}

Popualasi penelitian ini adalah perusahaan manufaktur yang terdaftar di Bursa Efek Indonesia (BEI) dari tahun 20142016. Metode pengambilan sampel dalam penelitian ini menggunakan teknik purposive sampling. Data yang digunakan dalam penelitian ini adalah data sekunder dari laporan tahunan perusahaan, maupun laporan berkelanjutan perusahaan manufaktur. Pengumpulan data dilakukan dengan teknik (archival) melalui sumber data di peroleh melalui situs resmi BEI : www.idx.co.id.

\section{Ekspropriasi}

Besaran related party transaction (RPT) menjadi proksi variable dependen dari konsep ekspropriasi yang biasa dilakukan melalui dua kategori berdasarkan penyajian laporan keuangan yaitu, Neraca pada item (asset \& liabilities) dan Laba-Rugi, pada item (sales \& expenses). Peraturan OJK Nomor VIII.G.7, tentang penyajian laporan keuangan, menjelaskan bahwa transaksi dangan pihak berelasi dapat dilihat pada catatan atas laporan keungan dengan melihat : (1) Akun aktiva, yang terkait pihak berelasi; (2) Akun kewajiban yang terkait pihak berelasi; (3) Jumlah penjualan yang terkait dengan hubungan pihak berelasi; (4) Jumlah masing-masing pembelian atau beban dari hubungan pihak berelasi. Selanjutnya total dari masing-masing kategori tersebut akan dibagikan dengan total equity, yang bertujuan untuk mengetahui dampak dari adanya transaksi pihak berelasi terhadap pemegang saham yang akan di bagi dalam dua kategori : 
Kategori 1 :

$R T P A L=\frac{R P T \text { asset }+ \text { RPT liabilities }}{\text { Equity }}$

Kategori 2 :

$$
R T P S E=\frac{R P T \text { sales }+ \text { RPT expenses }}{\text { Equity }}
$$

Keterangan:

RPT AL : Transaksi pihak berelasi (Asset \& Liabilities)

RPT SE : Transaksi pihak berelasi (sales \& Expenses)

\section{Pyramid of structure}

Konsep Pyramid of structure merupakan salah satu bentuk konsentrasi kepemilikan untuk tujuan meningkatkan kontrol terhadap perusahaan. Jika semakin besar deviasi hak kontrol dan hak arus kas, maka semakin tinggi upaya peningkatan kontrol oleh pemegang saham pengendali melebihi hak arus kasnya (La Porta et al., 1999; Cheung et al. 2006; Siregar, 2007,2008; dan Yudhiyanto \& Diyanty, 2016). Dalam penelitian ini, cash flow right leverage (CFR_L) akan di gunakan sebagai proksi dari konsep pyramid of structure, yang ditentukan dari deviasi antara hak kontrol dan hak arus kas. Karena hak kontrol lebih besar atau minimal sama dengan hak aliran kas, maka cash flow right leverage adalah positif atau nol. Sehingga dapat dirumuskan sebagai berikut;

CFR_L = Hak kontrol - Hak arus kas (Cheung et al., 2006)

\section{Pengungkapan Transaksi Pihak Berelasi}

Pengungkapan transaksi pihak berelasi didasarkan pada penelitian (Juvita \& Siregar, 2013; Apriani, 2016; dan Utama, 2015). Untuk mengidentifikasi informasi pengungkapan RPT, dapat diperoleh dari aspek yang di wajibkan oleh regulasi di Indonesia melalui PSAK no 7 Revisi (2015) dan peraturan Bapepam Nomor VIII.G.7 tentang sifat dan transaksi pihak berelasi. Prosedur scoring digunakan dengan penilaian dikotomi, yaitu dengan memberikan penilaian 1 pada indikator RPT yang diungkapkan dan nilai 0 jika indikator RPT tidak diungkapkan pada setiap aspek oleh perusahaan. Untuk menghitungan pengungkapan transaksi pihak berelasi atau RPT dapat diperoleh dari membagikan nilai dari aspek yang diungkapkan perusahaan dengan total nilai keseluruhnya dari aspek pengungkapan. Sehingga dapat dirumuskan adalah sebagai berikut :

$$
\text { disc_RPT }=\frac{n p}{t p} \times 100 \%
$$

\section{Keterangan :}

disc_RPT : Skor pengungkapan RPT 
$n p$ : Indikator yang diungkapkan pada aspek $i$

$t p$ : Jumlah indikator pada aspek $i$

\section{Good Corporate Governance}

Variabel moderasi dalam penelitian ini adalah penerapan corporate governance (CG) atau tata kelola perusahaan. Prosedur dalam melakukan scoring akan merujuk pada pertanyaan-pertanyaan lima aspek utama melalui metode penilaian corporate governance index yang di kembangkan oleh OECD. Terdapat 184 poin penting dalam penilaian corporate governance yang diwajibkan oleh ACMF. Masing-masing dari poin penilaian tersebut, berasal dari aspek Rights of shareholders (26), Equitable treatment of shareholders (17), Role of Stakeholders (21), Disclosure and Transparency (41), dan Responsibilities of the Board (79). Perhitungan index CG dalam penelitian ini dapat dirumuskan sebagai berikut:

$$
\begin{gathered}
C G I=\frac{\text { Jumlah item yang dipublikasikan }}{\text { Total keseluruhan item indikator OECD }} \\
\text { (Agustina, 2016) }
\end{gathered}
$$

\section{Model Penelitian}

Analisis data dalam penelitian ini menggunakan dua jenis analisis regresi yaitu, analisis regresi berganda (Multiple
Regression Analysis) dan Moderated Regression Analysis (MRA). Penggunaan dari kedua teknik analisis ini, dikarenakan ingin menguji pengaruh variabel independen terhadap variable dependen dengan dimoderasi oleh variabel pemoderasi. Variabel dependen yang dianalisis adalah RPT AL dan RPT SE, dan variable independennya adalah CFR_L dan disc_RPT, sedangkan CG_I sebagai variabel moderasi. Dalam penelitian ini akan menggunakan dua model persamaan regresi, dengan tujuan melihat dominasi tindakan ekspropriasi melalui RPT AL dan RPT SE. Berikut persamaan model regresi:

\section{Persamaan Model Penelitian Pertama :}

$$
\text { RPT } A L=\alpha+\beta_{1} \text { CFR_L } \mathrm{L}_{\mathrm{it}}+\beta_{2} \text { disc_RPT }_{\mathrm{it}}+
$$

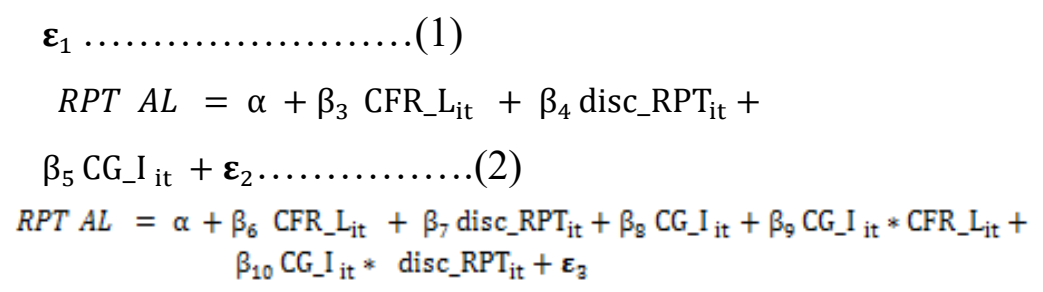

$$
\begin{aligned}
& \text { Persamaan Model Penelitian Kedua : } \\
& R P T S E=\alpha+\beta_{11} \text { CFR_L } L_{i t}+\beta_{12} \text { disc }_{-} \mathrm{RPT}_{\mathrm{it}}+ \\
& \varepsilon_{1} \ldots \ldots \ldots \ldots \ldots \ldots . . . \ldots(1) \\
& \text { RPT SE }=\alpha+\beta_{13} \text { CFR_L }_{\text {it }}+\beta_{14} \text { disc_RPT }_{\text {it }}+ \\
& \beta_{15} \text { CG_I it }+\varepsilon_{2} \ldots \ldots \ldots \ldots . .(2) \\
& \text { RPT SE }=\alpha+\beta_{16} \text { CFR_L } \mathrm{L}_{\mathrm{it}}+\beta_{17} \text { disc_RPT } \mathrm{it}_{\mathrm{it}}+ \\
& \beta_{18} C_{-} I_{i t}+\beta_{19} \text { CFR_L } L_{i t} * C G_{-} I_{i t}+\beta_{20} \text { disc_RPT }_{\text {it }} * \\
& \text { CG_I } \mathrm{I}_{\text {it }}+\varepsilon_{2} \ldots \ldots \ldots \ldots \text {...... (3) }
\end{aligned}
$$


Keterangan :

RPT AL : Ekspropriasi melalui transaksi pihak berelasi melalui asset dan liabilities pada perusahaan $i$ tahun ke $\mathrm{t}$

RPT SE : Ekspropriasi melalui transaksi pihak berelasi melalui sales dan expenses pada perusahaan $i$ tahun ke $\mathrm{t}$

$\alpha \quad$ : Konstanta

$\beta_{1}-\beta_{5} \quad$ : Koefisien variable independen pada perusahaan $i$ tahun ke $\mathrm{t}$
CFR_L : Selisih hak kontrol dan hak arus kas pada perusahaan $i$ tahun ke $\mathrm{t}$

disc_RPT : Pengungkapan transaksi pihak berelasi pada perusahaan $i$ tahun ke $\mathrm{t}$

CG_I : indeks Corporate governance pada perusahaan $i$ pada tahun ke $\mathrm{t}$

\& : Error

\section{HASIL PENELITIAN DAN PEMBAHASAN}

Tabel 5.1

Statistik Deskriptif RPT AL dan RPT SE

\begin{tabular}{|c|c|c|c|c|c|}
\hline Variabel & $\mathbf{N}$ & Minimum & Maximum & Rata-rata & $\begin{array}{c}\text { Std. } \\
\text { Deviasi }\end{array}$ \\
\hline RPT AL & 96 & 0,000 & 1,14 & 0,1458 & 0,21659 \\
\hline RPT SE & 96 & 0,000 & 5,66 & 0,5242 & 0,94270 \\
\hline CFR_L & 96 & 0,000 & 0,25 & 0,0791 & 0,08296 \\
\hline disc_RPT & 96 & 0,118 & 1,00 & 0,5514 & 0,23309 \\
\hline CG_I & 96 & 0,146 & 0,37 & 0,2438 & 0,05587 \\
\hline
\end{tabular}

Berdasarkan hasil penyajian data pada table diatas, dapat simpulkan bahwa nilai rata-rata RPT AL (asset, liabilitas) adalah sebesar 0,1458, sedangkan RPT SE (sales, expenses) adalah sebesar 0,5242. Artinya besaran transaksi pihak berelasi yang dilakukan perusahaan melalui sales dan expenses lebih besar dibandingkan transaksi pihak berelasi melalui asset dan liabilitas. Oleh karenanya, pemegang saham lebih merasakan dapak dari transaksi pihak berelasi yang tinggi pada RPT SE.

$$
\text { Pyramid of structure yang }
$$
diproksikan pada CFR_L (cash flow right 
laverage) memiliki nilai rata-rata sebesar 0,079. Artinya terdapat upaya yang dilakukan oleh pemegang saham pengendali melalui peningkatan hak kontrol dibandingkan hak arus kasnya melalui kepemilikan piramida walaupun sedikit yaitu $7 \%$. Nilai maksimum dan minimum Pyramid of structure masing-masing sebesar 0,25 dan 0,000. Nilai standar deviasi variabel ini sebesar 0,082. Nilai standar deviasi yang lebih besar dari nilai rata-rata mengindikasikan bahwa terdapat variasi yang tinggi antara nilai minimum dan maksimum selama periode pengamatan.

Pengungkapan RPT yang

diproksikan pada disc_RPT memiliki nilai rata-rata sebesar -0,551, artinya tingkat kepatuhan perusahaan dalam mengungkapkan transaksi pihak berelasi yang diwajibkan oleh regulasi di Indonesia sudah efektif, namun yang diungkapkan oleh perusahaan umumnya transaksi pihak berelasi yang sifatnya efisien. Nilai maksimum dan minimum sebesar 0,118 dan 1,00 sedangkan stadar deviasinya 0,521. Nilai standar deviasi yang lebih kecil dari nilai rata-rata mengindikasikan bahwa terdapat variasi kecil antara nilai minimum dan maksimum selama periode pengamatan atau tidak terdapat kesenjangan yang besar dari pengungkapan transaksi pihak berelasi.

Peran tata kelola perusahaan yang diproksikan pada indeks pengungkapan corporate governance atau CG_I memiliki nilai rata-rata, yaitu sebesar 0,244, artinya pelaksanaa corporate governance didalam perusahaan belum mampu berjalan secara efektif, hal ini dapat disebabkan karena terdapat beberapa item pengungkapan yang belum dilaksanakan oleh perusahaan pada aspek peran pemangku kepentingan (stakeholders). Lebih lanjut, nilai maksimum dan minimum pada variabel CG_I adalah sebesar 0,146 dan 0.37 , sedangkan stadar deviasinya sebesar 0,056. Nilai standar deviasi yang lebih kecil dari nilai rata-rata mengindikasikan bahwa terdapat variasi kecil antara nilai minimum dan maksimum selama periode pengamatan atau tidak terdapat kesenjangan yang besar dari corporate governance. 


\section{Hasil Analisi Regresi}

Tabel 5.2

Hasil Analisis Regresi (RPT AL)

\begin{tabular}{|c|c|c|c|c|c|c|}
\hline Variabel & Koefisien & Nilai. & \multicolumn{2}{|c|}{ R-square Adj. R-Square } & Sig. F & Keterangar: \\
\hline Konstanta $(\alpha)$ & 0,081 & 1,249 & & & & Persamaan 1 \\
\hline CFR_L & $-0,054$ & $-0,192$ & 0,011 & 0,010 & 0,532 & (Hipotesis \\
\hline disc_RPT & 0,108 & 1,028 & & & & $1 \& 2)$ \\
\hline Konstanta $(\alpha)$ & 0,290 & 2,335 & & & & \\
\hline CFR_L & 0,009 & 0,031 & 0,051 & 0,020 & 1,649 & Persamaan 2 \\
\hline disc_RPT & 0,143 & 1,363 & & & & (Hipotesis \\
\hline CG_I & $-0,999 *$ & $-1,962$ & & & & $3 \& 4)$ \\
\hline Konstanta $(\alpha)$ & $-0,703$ & $-1,236$ & & & & \\
\hline CFR_L & 0,378 & 0,287 & & & & Persamaan 3 \\
\hline disc_RPT & $1,630^{*}$ & 1,934 & 0,048 & 0,033 & 1,651 & (Hipotesis \\
\hline CG_I & 3,401 & 1,357 & & & & $3 \& 4)$ \\
\hline interaksai CFR_L.CG_I & $-0,695$ & $-0,132$ & & & & \\
\hline interaksidisc_RPT.CG_I & $-6,655^{*}$ & $-1,774$ & & & & \\
\hline
\end{tabular}

Tabel 5.3

Hasil Analisis Regresi (RPT SE)|

\begin{tabular}{|c|c|c|c|c|c|c|}
\hline Variabel & $\begin{array}{c}\text { Koefisien } \\
\text { Regresi }\end{array}$ & $\underset{t}{\text { Nilai. }}$ & \multicolumn{2}{|c|}{$R$-square Adj. R-Square } & Sig. F & Keterangan \\
\hline Konstanta $(\alpha)$ & 0,162 & 0,580 & \multirow{3}{*}{0,026} & \multirow{3}{*}{0,005} & \multirow{3}{*}{1,243} & \multirow{3}{*}{$\begin{array}{c}\text { Persamaan } 1 \\
\text { (Hipotesis } \\
1 \& \text { 2) }\end{array}$} \\
\hline CFR_L & $-0,485$ & $-0,400$ & & & & \\
\hline disc_RPT & 0,704 & 1,558 & & & & \\
\hline Konstanta $(\alpha)$ & 0,726 & 1,342 & \multirow{4}{*}{0,041} & \multirow{4}{*}{0,010} & \multirow{4}{*}{1,326} & \multirow{4}{*}{$\begin{array}{c}\text { Persamaan } 2 \\
\text { (Hipotesis } \\
3 \& 4 \text { ) }\end{array}$} \\
\hline CFR_L & $-0,315$ & $-0,259$ & & & & \\
\hline disc_RPT & $0,799^{*}$ & 1,747 & & & & \\
\hline $\mathrm{CG}$ & $-2,696$ & $-1,216$ & & & & \\
\hline Konstanta $(\alpha)$ & $-1,275$ & $-0,508$ & \multirow{6}{*}{0,049} & \multirow{6}{*}{0,004} & \multirow{6}{*}{0,918} & \multirow{6}{*}{$\begin{array}{c}\text { Persamaan } 3 \\
\text { (Hipotesis } \\
3 \& 4 \text { ) }\end{array}$} \\
\hline CFR_L & 0,566 & 0,097 & & & & \\
\hline disc_RPT & 3,769 & 1,013 & & & & \\
\hline CG_i & 6,161 & 0,557 & & & & \\
\hline interaksiCFR_L.CG_I & $-1,976$ & $-0,085$ & & & & \\
\hline interaksidisc_RPT.CG_I & $-13,285$ & $-0,802$ & & & & \\
\hline
\end{tabular}

Analisis regresi berganda digunakan untuk mengetahui pengaruh variabel independen terhadap variabel dependen baik berupa arah negatif atau positif, berdasarkan hipotesis penelitian yang telah dirumuskan. Untuk mengetahui hipotesis di terima atau 
ditolak, dapat diketahui dengan melihat nilai signifikasi. apabila nilai signifikasi lebih kecil dari alfa $5 \%$ maka dapat disimpulkan bahwa hipotesis diterima. Pengujian hipotesis 1 dan 2 dilakukan dengan melihat koefisien dan signifikansi pada persamaan 1 , sedangkan hipotesis 3 dan 4 diuji dengan melihat koefisien dan signifikasi pada persamaan 2 dan 3.

- Hipotesis satu menyatakan bahwa pyramid of structure (CFR_L) berpengaruh positif terhadap tindakan ekspropriasi melalui RPT AL dan RPT SE. Hipotesis tersebut dapat didukung jika nilai koefisiennya bernilai positif dengan alfa dibawah 5\%. Seperti tampak pada tabel 5.2 dan 5.3 menunjukan nilai koefisien yang negatif dan tidak signifikan, sehingga data tidak mendukung hipotesis 1, (baik H1a dan H1b).

- Hipotesis kedua menyatakan bahwa pengungkapan RPT (disc_RPT) berpengaruh negatif terhadap tindakan ekspropriasi melalui RPT AL dan RPT SE. Hipotesis tersebut dapat didukung jika nilai koefisiennya bernilai negatif dengan alfa dibawah 5\%. Seperti tampak pada tabel 5.2 dan 5.3 menunjukan nilai koefisien yang positif dan tidak signifikan, sehingga data tidak mendukung hipotesis 2 (baik H2a dan $\mathrm{H} 2 b)$.

- Hipotesis ketiga menyatakan bahwa tata kelola perusahaan (CG_I) mampu memperlemah pengaruh positif pyramid of structure terhadap tindakan eksproprasi melalui RPT AL dan RPT SE. Hipotesis tersebut dapat didukung jika nilai koefisiennya bernilai negatif dengan alfa dibawah 5\%. Seperti tampak pada tabel 5.2 dan 5.3 menunjukan nilai koefisien yang negatif, namun tidak signifikan, sehingga data tidak mendukung hipotesis 3 (baik H3a dan H3b).

- Hipotesis keempat menyatakan bahwa, tata kelola perusahaan mampu memperkuat pengaruh negatif antara pengungkapan RPT dengan tindakan ekspropriasi melalui RPT AL dan RPT SE. Hipotesis tersebut dapat didukung jika nilai koefisiennya bernilai negatif dengan alfa dibawah 5\%. Seperti tampak pada tabel 5.2 dan 5.3 menunjukan nilai koefisien yang negatif, namun signifikan hanya pada RPT AL dan tidak signifikan pada RPT SE. oleh karenanya data mendukung hipotesis $\mathrm{H} 4 \mathrm{a}$

\section{Pembahasan}


Masalah agensi tipe kedua merupakan isu yang sentral, terkait konflik kepentingan yang terjadi antara pemegang saham pengendali dan pemegang saham non pengendali dalam kepemilikan terkonsentrasi melalui mekanisme kepemilikan piramida. Menurut argument negative entrenchment effect (NEE), pemegang saham pengendali sering memanfaatkan hak kontrolnya yang tinggi untuk memperoleh keuntungan privat seperti melakukan tindakan ekspropriasi terhadap pemegang saham non pengendali atau monoritas, melalui pyramid of structure atau kepemilikan piramida.. Hasil penelitian ini tidak mendukung argumen NEE dalam hipotesis pertama, hasil penelitian ini sejalan dengan Cheung et al. (2006). Peneliti menduga bahwa pemegang saham pengendali pada perusahaan manufaktur di Indonesia dengan kepemilikan piramida, lebih memilih untuk melakukan prop-up atau menopang perusahaan-perusahaan yang berafiliasi. Hal ini disebabkan karena kestabilan perekonomian di Indonesia yang tidak menentu terjadi selama periode pengamatan dari tahun 2014-2016.

Masalah ketidak asimetrian informasi menjadi isu yang sentral dalam menilai efektifitas perusahaan secara keseluruhan. Hal ini biasanya terjadi pada perusahaan keluarga dengan kepemilikan terkonsentrasi. Oktaviana (2016), menyatakan bahwa, pemegang saham pengendali memilih untuk mengungkapkan sedikit informasi disebabkan keterlibatanya sebagai manajemen dapat mengetahui informasi internal perusahaan secara langsung sehingga mereka beranggapan tidak perlu untuk mengungkapkan informasi kepada stakeholder lainnya. Oleh karenanya, dibutukan peran regulasi untuk mendisiplinkan perusahaan guna meningkatkan transparansi laporan keuangan khususnya transaksi pihak berelasi seperti dalam peraturan BAPEPAM Nomor. VIII.G.7 (Kep-347/BL/2012) dan PSAK no 7. Hasil penelitian ini tidak mendukung hipotesis 2 yang menyatakan bahwa pengungkapan RPT memiliki pengaruh negatif terhadap tindakan ekspropriasi. Hasil penelitian ini mengindikasikan bahwa perusahaan di Indonesia cenderung mengungkapkan transaksi pihak berelasi, namun transaksi yang diungkapkan tidak bersifat opurtunistik atau merugikan, sehingga tindakan ekspropriasi tidak terjadi pada perusahaan.

Secara teori, salah satu alasan mekanisme CG perlu diterapkan adalah, adanya kepemilikan terkonsentrasi baik individu atau keluarga, yang akan memiliki 
kebijakan penuh untuk menetukan arah perusahaan yang menyebabkan timbulnya benturan kepentingan antara pemegang saham pengendali dan non pengendali. Untuk mengurangi dominasi pengendali atau pihak keluarga dalam perusahaan, maka diwajibkan mengacu pada peraturan dan prisip-prinsip good corporate governance (GCG) yang secara tidak langsung mendisiplinkan perusahaan melalui aspek penilaian tata kelola perusahaan atau corporate governance index. Hal ini dapat menjadi acuan perusahaan untuk bertindak independen untuk menjamin menjamin keadilan bagi seluruh pemegang saham dan investor, serta untuk mendapatkan kepercayaan publik. Hasil penelitian ini tidak mendukung hipotesis ke 3, hal ini dapat dipengaruhi oleh penerapan tata kelola yang belum sepenuhnya dilaksanakan oleh perusahaan. Terlebihnya lagi, jika tata kelola perusahaan lebih didominasi oleh institusi legal-formal oleh pihak keluarga. Hal ini akan menyebabkan adanya insentif yang kuat pihak keluarga yang menjabat sebagai komisaris atau direksi sehingga dapat mempengaruhi keputusan dewan komisaris yang independen pada perusahaan.

Hasil penelitian ini menemukan pengaruh signifikan tata kelola perusahaan dalam meningkatkan hubungan negatif antara pengungkapan RPT dan ekspropriasi melalui RPT AL, namun tidak signifikan pada RPT SE. penelitian ini menemukan dua implikasi yang berbeda. Pertama, Hasil penelitian ini didukung oleh beberapa hasil penelitian terdahulu seperti, Utama (2015); Juvita \& Siregar (2013); Akmyga \& Mita (2015). Hal ini terkait dengan masalah ketidakasimetrian informasi, yang terjadi pada perusahan yang dikendalikan pemegang saham pengendali atau keluarga. Keterlibatan pengendali sebagai pihak insider menyebabkan rendahnya kualitas keterbukaan informasi. Kedua, peran tata kelola perusahaan tidak digunakan untuk memperkuat pengungkapan RPT sebagai upaya mengurangi tindakan ekspropriasi khususnya RPT SE. Hal ini juga disebabkan oleh tingginya kesadaran perusahaan yang hanya menerapkan GCG sebagai suatu kebutuhan, bukan hanya sekedar untuk memenuhi kepatuhan terhadap regulasi di Indonesia. Selain itu, ditemukan adanya beberapa item pengungkapan yang belum dilaksanakan oleh perusahaan seperti, pada item penyelenggaraan RUPS, pemungutan suara, dan perlindungan kepada pemangku kepentingan. Hal ini yang menyebabkan tata kelola perusahaan sebagai variabel moderasi 
tidak berpengaruh terhadap ekspropriasi yang dilihat dari RPT SE.

\section{KESIMPULAN DAN SARAN}

Hasil penelitian ini memberikan bukti adanya indikasi ekspropriasi sangat dominan dilakukan melalui transaksi pembelian dan penjualan dibandingkan transaksi pihak berelasi dari aspek piutang dan hutang. oleh karenanya, peneliti menyimpulkan bahwa manipulasi harga jual-beli dibawah nilai wajar sering dilakukan oleh pihak pengendali, sehingga menimbulkan transaksi yang mengandung benturan kepentingan. Lebih lanjut, hasil penelitian ini gagal membuktikan pengungkapan transaksi pihak berelasi dapat mengurangi tindakan ekspropriasi. Hal ini diduga karena sebagian besar transaksi berelasi yang diungkapkan oleh perusahaan bersifat efisien.

Hasil penelitian ini juga membuktikan bahwa, keberadaan peran tata kelola perusahaan dapat mengurangi transaksi-transaksi yang bersifat opurtunistik. Namun, hasil penelitian ini gagal membuktikan peran tata kelola perusahaan dalam mengurangi kontrol pemegang saham pengendali yang tinggi. Hal ini disebabkan karena keterlibatan pemegang saham pengendali sebagai Board of Director (BOD), dapat mempengaruhi penilaian dari tata kelola perusahaan semakin rendah. Namun, hasil penelitian ini membuktikan bahwa, peran tata kelola mampu meningkatkan keterbukaan informasi, sehingga dapat mengurangi tindakan ekspropriasi melalui transaksi pihak berelasi. Penelitian ini juga menyimpulkan bahwa perusahaan di Indonesia masih menerapkan GCG sebagai suatu kebutuhan, bukan hanya sekedar untuk memenuhi kepatuhan terhadap regulasi di indonesia.

Hasil penelitian ini dapat menjadi masukan bagi pihak regulasi untuk meningkatakan kebijakanya melalui peraturan-peraturan yang telah ada, dengan mewajibkan perusahaan melakukan pengungkapan struktur kepemilikan ultimate dan pembatasan terkait kosentrasi kepemilikan, seperti membatasi kepemilikan saham dan jabatan pihak keluarga yang merengkap menjadi dewan direksi atau komisaris pada perusahaan berafiliasi.

Menelusuri kepemilikan pengendali akhir melalui rantai kepemilikan, menjadi keterbatasan yang dialami oleh peneliti, karena terdapat beberapa perusahaan yang tidak mengungkapkan informasi mengenai pengendali akhir perusahaan didalam laporan tahunan. Selanjutnya, hasil 
penelitian ini masih menunjukan adjusted $R^{2}$ yang masih rendah, hal ini diduga terdapat varibel lain yang tidak diikutsertakan dalam penelitian ini. Selanjutnya konsep ekspropriasi yang diproksikan dari transaksi melalui aset, liabilitas, penjualan dan pembelian dianggap keterbatasan, karena transaksi tersebut dapat bersifat opurtunistik atau efisien.

Diharapkan untuk penelitian selanjutnya untuk melakukan penelusuran lebih jauh terkait kepemilikan pengendali akhir melalui rantai kepemilikan berpola pyramid of structure. Selain itu penelitian selanjutnya perlu menambahkan beberapa variabel penelitian yang berhubungan dengan tidakan ekspropriasi seperti, keterlibatan pemegang saham kedua, dan melihat dampak tindakan ekspropriasi terhadap kebijakan deviden. Lebih lanjut penelitian selanjutnya harus mampu menelusuri lebih jauh sifat dari transaksi pihak berelasi, yang dianggap opurtunistik dan efisien.

\section{DAFTAR PUSTAKA}

ACMF., 2011, ASEAN Corporate Governance Scorecard. ACMF.

Akmyga, S, F., \& Mita, A, F., 2015, Pengaruh Struktur Corporate Governance dan Kualitas Audit terhadap Pengungkapan Kompensasi Manajemen Kunci di Laporan Keuangan. Jurnal Akuntansi dan Keuangan Indonesia, Vol. 12, No 1, $19-36$.

Agustina, I., 2016, Pengaruh Corporate Governance terhadap Nilai Perusahaan Melalui Enterprise Risk Management (Erm) Dan Sustainability Management. Tesis. Fakultas Ekonomi dan Bisnis Universitas Brawijaya.

Dewi, C, A., 2014, Faktor-Faktor yang Mempengaruhi Ekspropriasi di Indonesia. Skripsi. Fakultas Ekonomi dan Bisnis Universitas Brawijaya.

Apriani, H, W., 2015, Pengaruh Corporate Governance dan Karakteristik Perusahaan Terhadap Luas Pengungkapan Transaksi Pihak Berelasi Di Indonesia. Jurnal Akuntansi Indonesia, Vol. 4, No. 1, 36 -50 .

Chang, S, J., 2003, Ownership Structure, Expropriation, And Performance Of Group-Affiliated Firms In Korea. Academy of Management Journal, Vol. 46, 238-253.

Cheung, Y,L., Rau, P, R., \& Stouraitis, A., 2006, Tunneling, Propping, and Expropriation: Evidence From Connected Party Transactions in Hong Kong, Journal of Financial Economics, Vol. 82, No. 2, 343-386.

Dewi, C, A., 2014, Faktor-Faktor yang Mempengaruhi Ekspropriasi di Indonesia. Skripsi. Fakultas Ekonomi dan Bisnis Universitas Brawijaya.

Du, J., He, Q., \& Yuen, S, W., 2013, Tunneling and The Decision To Go Private: Evidence from Hong Kong, 
Pacific Basin Finance Journal, Vol. 22, No. 1, 50-68.

Dyanty, V., Utama S., Rossieta H., dan Veronica S., 2012, Pengaruh Kepemilikan Pengendali Akhir terhadap Transaksi Pihak Berelasi, Makalah dalam Simposium Nasional Akuntansi XV Banjarmasin.

Fama, E., \& Jensen, M. C., 1983, Separation of Ownership and Control, Journal of Law and Economics, Vol. 26, 301325.

Fernando, G. D., Schneible, R. A., \& Suh, S., 2013, Family Firms and Institutional Investors, Family Business Review, Vol. 27, No. 4, 328 345.

Fitri, N., 2015, Dampak Struktur Kepemilikan Terhadap Risiko Ekspropriasi. Tesis, Fakultas Ekonomi dan Bisnis Universitas Brawijaya.

Friedman, E., Johnson, S., \& Mitton, T., 2003, Propping and Tunneling. Journal of Comparative Economics. Vol. 31, No. 4, 732-750.

Glaeser, E., Johnson, S., \& Shleifer, A., 2001, Coase versus the Coasians. Quarterly Journal of Economics, Vol. 116, 853-899.

Grossman, S,J., \& Hart, O.D., 1987, One Share/ One Vote and the Market For Corporate Control. National Bureau of Economic Research. Working Paper No. 2347.

Henry, E., Gordon, E., Reed, B., \& Louwers, T., 2012, The Role of Related Party Transactions in Fraudulent Financial Reporting, Journal of Forensic \&
Investigative Accounting, Vol. 4, No.1, $186-213$

Hwang, N,C,R., Chiou, J.R., \& Wang, Y,C, 2013, Effect of Disclosure Regulation On Earnings Management Through Related-Party Transactions: Evidence from Taiwanese firms operating in China, Journal of Accounting and Public Policy, Vol. 32, No. 4, 292313.

Jensen, M. C., \& Meckling, W. H., 1976, Theory of the Firm: Managerial Behaviour, Agency Costs, and Ownership Structure. Journal of Financial Economics, Vol. 3, No. 4, 305-360.

Juvita, D., \& Siregar, S, V., 2013, Pengaruh Corporate Governance Terhadap Hubungan Besaran Dan Pengungkapan Hubungan Pihak Berelasi Dengan Manajemen Laba : Studi Empiris Perubahan PSAK no. 7. Jurnal Akuntansi dan Auditing, Vol. 10, No. 1, 45-67.

Johnson, S., Porta, R. L., Lopez-de-silanes, F., \& Shleifer, A., 2000, Tunneling. Discussion Paper Number, 1887

Kim, J., 2005, Accounting Transparency of Korean Firms: Measurements and Determinant Analysis. Journal of American Academy of Business, Cambridge, Vol. 6, No. 2, 222 - 229

Kang, M., Lee, H, Y., Lee, M, G., \& Park, J, C., 2014, The Association between Related-Party Transactions and Control- Ownership Wedge: Evidence from Korea, Pacific-Basin Finance Journal, Vol. 29, 272-296.

La Porta, R., Lopez-de-Silanes, F., Shleifer, A., \& Vishny, R., 1999a, Investor 
Protection and Corporate Governance, Journal of Financial Economic, Vol. 58, No. 1-2, 3-27.

La Porta, R., Lopez-de-Silanes, F., \& Shleifer, A., 1999b, Corporate Ownership Around the World, Journal of Finance. 54, 471-517.

Lin, C., Chen, Y., \& Yen, J., 2014, On the Determinant of Bank Loan Contracts: The Roles of Borrowers' Ownership and Board Structures, The Quarterly Review of Economics and Finance, Vol. 54, 500-512

Liu, Q., \& Lu, Z, J., 2007, Corporate Governance and Earnings Management in the Chinese Listed Companies: A Tunneling Perspective, Journal of Corporate Finance, Vol. 13, 881-906.

Lukviarman, Niki., 2016, Coporate Governance. Solo: PT Era Adicitra Intermedia.

Nekhili, M., \& Cherif, M., 2011, Related Parties Transactions And Firm's Market Value: The French Case. Review of Accounting and Finance, Vol. 10, No. 3, 291 - 315

Otoritas Jasa Keuangan., 2012, Peraturan Otoritas Jasa Keuangan Nomor VIII.G.7 tentang Pedoman Penyajian Laporan Keuangan. Jakarta: Otoritas Jasa Keuangan.
Panggabean, E., 2013, Diduga Corporate Crime, Sumalindo Digugat Bayar Rp 18,7 Triliun (Online). http://news.liputan6.com/read/729338/ diduga-corporate-crime-sumalindodigugat-bayar-rp-187-triliun, (Diakses 30 Maret 2017)

Pagano, \& Röell., 1998, The Choice of Stock Ownership Structure: Agency Costs, Monitoring and the Decision to Go Public. The Quarterly Journal of Economics, Vol. 113, 187-188.

Peng, W, Q., Wei, K.C., \& Yang, Z., 2011, Tunneling Or Propping: Evidence From Connected Transactions In China. Journal of Corporate Finance. Vol. 17, No. 2, 306-325.

Pozzoli, M., \& Venuti M., 2013, Related Party Transactions and Financial Performance: Is There a Correlation? Empirical Evidence from Italian Listed Companies, Open Journal of Accounting, Vol. 3, 28-37.

Sari, C, S., \& Baridwan, Z., 2014, Current Asset Tunneling And Firm Performance In An Emerging Market, Jurnal Akuntansi dan Keuangan Indonesia, Vol. 11, No. 2, 165 - 176.

Siagian, F., Siregar, V, S., \& Yan, R., 2013, Corporate Governance, Reporting Quality, And Firm Value: Evidence From Indonesia, Journal of Accounting in Emerging Economies, Vol. 3, No. 1, 4-20.

Siregar, B., 2007, Pengaruh Pemisahan Hak Aliran Kas Dan Hak Kontrol Terhadap Dividen. Simposium nasional Akuntansi X. Universitas Hasanudin, Makassar, 1-44. 
Siregar, B., 2008, Ekspropriasi Pemegang Saham Minoritas dalam Struktur Kepemilikan Ultimat. Jurnal Riset Akuntansi Indonesia, Vol. 1, 237-263.

Utama, C, A., 2015, Penentu Besaran Transaksi Pihak Berelasi: Tata Kelola, Tingkat Pengungkapan, Dan Struktur Kepemilikan, Jurnal Akuntansi dan Keuangan Indonesia, Vol.12, No. 1, $37-54$

Utama, C. A., \& Susmantoro, T, D., 2012, Company Disclosure in Indonesia: Corporate Governance Practice, Ownership Structure, Competition, and Total Assets. Asian Journal of Business and Accounting, Vol 5, No. 1, 1-25.

Utama, C, A., \& Utama, S., 2014. Corporate Governance, Size and Disclosure of Related Party Transactions, and Firm Value: Indonesia Evidence, International Journal of Disclosure and Governance, Vol. 11, No. 4, 341365.

Ying, Q., \& Wang, L., 2013, Propping by Controlling Shareholders, Wealth Transfer and Firm Performance: Evidence from Chinese Listed Companies, Journal of Accounting Research.Vol. 6, 133-147.

Yodhianto, A., \& Diyanty, V., 2016, Efek Entrenchment dan Alignment Pengendali Akhir Keluarga dan Peran Dewan Komisaris Terhadap Biaya Utang, Simposium Nasional Akuntansi XIX, Lampung. 